\title{
UM PROCEDIMENTO RAZOÁVEL PARA O JULGAMENTO EQUITATIVO: A VERTENTE ABSTRACIONISTA
}

\section{Roosevelt Arraes ${ }^{1}$}

\section{Resumo}

O artigo versa sobre a justificação e a formulação de um procedimento razoável que oriente julgamentos equitativos. A equidade é o recurso do intérprete contra a lei e o precedente, quando estes produzem respostas iníquas. Ante o risco de a equidade produzir arbitrariedades, o artigo investigou a possibilidade de se justificar, constituir e exemplificar a aplicação de um procedimento razoável para o julgamento equitativo a partir da vertente abstracionista, na tentativa de se reduzir a discricionariedade do intérprete. A metodologia consistiu na análise empírica de precedentes do STF que aplicaram princípios de algumas teorias da justiça, a partir dos quais se introduziu o conceito de "razoabilidade" de Jonh Rawls para, então, formular-se um procedimento que identifique a teoria da justiça que oferece uma solução ao caso concreto, oportunizando-se a análise de teorias concorrentes, após o que deverá encontrar-se pontos de congruência, excluindo-se os argumentos que incorrem em desintegração ou hiperintegração constitucional (teste de delimitação). Em seguida deve-se avaliar o grau de imparcialidade e razoabilidade da proposição por meio dos testes de justificação, confrontação e transcendência. Caso remanesça mais de uma opção para a solução do caso, a opção ideológica deverá ser assumida explicitamente para que possa ser criticada e revisada.

Palavras-chave: equidade, abstracionismo, procedimento, razoabilidade.

\section{INTRODUÇÃO}

A equidade é entendida como recurso do intérprete contra a lei e o precedente, nas hipóteses em que estes não são capazes de oferecer uma solução adequada ao caso concreto. Ao afastar-se dos contornos do direito posto, o julgamento equitativo pode se tornar parcial e arbitrário (próximo ao campo do Político) ${ }^{2}$, na medida em que o raciocínio empregado para a resolução do caso difícil não for adequadamente justificado. Por outro lado, caso se estabeleçam procedimentos razoáveis para orientar o intérprete, pode-se almejar a possível ampliação do grau de imparcialidade e justificação dos critérios e enunciados que serão aplicados ao caso concreto, em

\footnotetext{
${ }^{1}$ Doutorando (2014) em Filosofia Jurídica e Política pela Pontifícia Universidade Católica do Paraná. Professor e pesquisador do Centro Universitário Curitiba - UNICURITIBA. Membro-pesquisador do Departamento de Filosofia na Pontifícia Universidade Católica do Paraná. E-mail: arraes@aac.adv.br

${ }^{2}$ Toda decisão equitativa é, em alguma medida política, no sentido de ser discricionária. Aliás, é discricionária num sentido especial, pois, equivale à discricionariedade do legislador. Como afirma Perelman, o magistrado é o legislador do caso concreto. Mas, uma
} 
substituição aqueles previamente estatuídos no direito positivado.

O artigo investigará a possibilidade de se justificar, constituir e aplicar procedimentos razoáveis para o julgamento equitativo a partir da vertente abstracionista, a qual vale-se das teorias da justiça para preparar a ponderação entre princípios e valores conflitantes. O problema é posto nos seguintes termos: é possível justificar, constituir e aplicar um procedimento razoável para o julgamento equitativo a partir da vertente abstracionista?

Apresentar-se-ão as vertentes que tratam do tema (a casualista e a abstracionista), demostrando-se que o emprego da equidade é necessário, uma vez que o funcionalismo jurídico positivista padece de limitações epistemológicas decorrentes da incorporação de valores, princípios e cláusulas gerais nas declarações internacionais de direitos e nas Constituições. É neste espaço que a equidade se (re)insere com a missão de apresentar soluções mais razoáveis que as oferecidas pelo direito posto. Diante disso, objetiva-se justificar, constituir e exemplificar a aplicação de um procedimento razoável para o julgamento equitativo a partir da vertente abstracionista, o qual deve prestar-se à orientação do intérprete de maneira a reduzir sua discricionariedade.

A metodologia utilizada consistiu no levantamento e análise empírica de precedentes do Supremo Tribunal Federal que aplicaram princípios de teorias da justiça em situações similares ao conceito de equidade desenvolvido neste artigo. A partir do exame das decisões buscou-se o viés teórico que serviu para fundamentar o procedimento razoável objeto da investigação, enfatizando-se o conceito de "razoabilidade" da teoria da justiça de John Rawls, a partir da qual formulou-se o referido procedimento para a avaliação das teorias da justiça que apresentam princípios (congruentes ou concorrentes) para a solução do caso.

O texto está dividido nos seguintes tópicos: a) apresentação das acepções da equidade, na qual se fará a distinção entre a vertente casualista (que prioriza a construção de soluções a partir do contexto do caso concreto) e a vertente abstracionista (que prioriza a construção da solução a partir de uma teoria geral sobre a justiça; b) caracterização da vertente abstracionista, exemplificando sua aplicação pelas Cortes brasileiras e mostrando as dificuldades de se escolher uma das teorias da justiça para interpretar um caso difícil; c) discussão sobre um ponto de partida razoável para o procedimento argumentativo na aplicação da equidade; d) fundamentação, constituição e exemplificação de um procedimento razoável para a adequada construção de uma solução equitativa.

Almeja-se que a formulação deste procedimento, com seus testes e justificações, seja capaz de, a partir da vertente abstracionista, mitigar a arbitrariedade no julgamento por equidade.

\section{ACEPÇÕES DA EQUIDADE}

decisão discricionária (política), que implica numa escolha valorativa não precisa ser arbitrária, violando a ordem jurídica existente vol.10, no. 03, Rio de Janeiro, 2017.pp. 1915-1942 
A equidade está na fronteira do direito. Nela encontram-se os elementos jurídicos, concernentes à imparcialidade, à regularidade e à consistência argumentativa. Ou seja, quanto à forma, a equidade ostenta atributos próprios das normas jurídicas. Mas, nela também estão presentes elementos extrajurídicos, os quais, ante a pretensão de se fazer valer a justiça, a razoabilidade ou o bom-senso, muitas vezes ocultam o caráter arbitrário de uma decisão que desvia da lei ou do precedente.

Nos confins do direito, lá onde o campo do Político se arvora é que se encontra a equidade, um campo duplo de juízos e argumentos que flerta com o decisionismo ${ }^{3}$. Nesse sentido, o conteúdo do juízo de equidade não é previamente definível ou delimitável.

Noutros termos, ante sua peculiaridade, não é possível defini-la por oposição, contraste ou negação. E quando se tenta defini-la internamente, não há nenhum critério (teórico, objetivo, jurídico ou político) a validá-la de maneira absolutamente neutra.

Apesar dessas dificuldades, é possível traçar um panorama da equidade a partir dos modelos teóricos ou dos procedimentos argumentativos que se empregam na solução de casos dificeis, o que permite, senão uma resposta definitiva sobre o problema do decisionismo, ao menos aponta alguns limites à atuação dos filósofos, juristas, dos administradores públicos e dos cidadãos envolvidos na discussão da interpretação dos princípios e das regras jurídicas.

Trata-se de duas perspectivas (a casualista e a abstracionista, que serão apontadas a seguir) que aparentemente se contradizem, mas, por fim se complementam. Elas não são totalmente independentes, mas, ao menos num plano mais abstrato, é possível distingui-las.

Seria possível sugerir outras acepções para a equidade, mas as apresentadas a seguir parecem organizar de maneira adequada duas grandes linhas do pensamento político, filosófico e jurídico que tratam do tema.

Uma linha toma a equidade a partir de casos concretos, e, a partir deles procura ter uma visão mais ampla da justiça. Esta linha, que remonta a Aristóteles e aos juristas do direito romano antigo, chega à modernidade, por exemplo, pelo pensamento de Chaïm Perelman. Sua aplicação se dá em três hipóteses:

“( ... a primeira, aquela a que Aristóteles alude, é a obrigação de aplicar a lei a um caso singular, no qual o legislador não pensara; a segunda se apresenta quando condições externas, tais como uma desvalorização da moeda, uma guerra ou catástrofe, modificam tanto as condições do contrato que sua execução estrita lesa gravemente uma das partes; a terceira se deve à evolução do sentimento moral, do que resulta que certas distinções, que o legislador, ou o juiz que havia enunciado o precedente, havia menosprezado no passado, se tornam essenciais na apreciação atual dos fatos." (PERELMAN, 1996, p. 163)

de maneira a torná-la insuportável como os comandos de um ditador num estado de exceção (campo do Político).

${ }^{3}$ Nesse sentido, afirma Carl Schmitt: "Cada decisión jurídica concreta contiene un elemento de indiferencia con respecto al contenido porque la conclusión jurídica no emana en su totalidade de sus premisas y el hecho de ser necesaria la decisión se conserva como elemento determinante autónomo." (SCHMITT, Carl. p. 90). 
Diante destas hipóteses não se aplica o precedente ou a lei, devendo-se construir uma solução mais adequada para o caso concreto, a qual é tão mais justa quanto mais os argumentos empregados forem capazes de se aplicar a outros casos similares, mas especialmente, se conseguir reposicionar a compreensão de institutos jurídicos, de maneira a construir uma teia argumentativa que complemente o ordenamento jurídico. Esta pretensão de complementação, segundo a teoria da argumentação de Perelman, se daria em dois níveis. Num primeiro, adapta-se o imperativo categórico, procurando universalizar as máximas que pretendem equacionar a questão. Num segundo, procura-se demonstrar que as opções concorrentes são menos justificáveis e imparciais.

Essa vertente é mais atenta às circunstâncias do caso concreto, porém, enfrenta dificuldades de aplicação num plano mais amplo, sendo, por isso mesmo, acusada de falta de objetividade e imparcialidade, o que revelaria seu caráter arbitrário e excessivamente Político. Esta é a vertente "casualista".

A outra vertente, que será analisada neste artigo, toma a equidade como um modelo mais geral e abstrato, que orienta as instituições mais relevantes da sociedade, para, então, verificar sua aplicabilidade em casos concretos. Nessa linha, têm-se as construções teóricas de contratualistas liberais modernos, como John Rawls, que intitula sua teoria de "justiça como equidade". Ao passo que esta vertente oferece um panorama institucional orientado para um fim específico, que no entender destes autores seria menos arbitrário, ela tem dificuldades na solução de casos particulares mais complexos. Eis a vertente "abstracionista”.

Apesar das diferenças entre tais formas de pensar a equidade, elas guardam algumas semelhanças, que podem ser assim resumidas: a) pressuposição da insuficiência do ordenamento jurídico; b) a possibilidade de aplicação da equidade, pelo Judiciário e pelo administrador público independentemente de previsão legislativa; c) a mitigação da força dos institutos clássicos do direito.

Tais vertentes dividem a atenção de juristas, políticos e filósofos de maneira inconciliável, e, a questão parece não estar perto de ser resolvida. Todavia, ao definir o âmbito da aplicação de cada qual, é possível, senão resolver o problema a partir dos fundamentos, ao menos justificar porque podem oferecer respostas menos arbitrárias aos problemas jurídico-políticos das sociedades democráticas modernas.

A seguir será apresentada a corrente abstracionista, a qual encontra exemplos de aplicação nas decisões do STF, e por esta razão, será analisada neste artigo indicando-se de que maneira ela pode ser tomada como um ponto de partida (possivelmente mais razoável do que a vertente casualista) para o processo argumentativo empregado na solução de casos difíceis.

\section{A VERTENTE ABSTRACIONISTA}

A vertente abstracionista propõe uma visão completa da justiça, que pode abranger as esferas da justiça política, econômica e social. Algumas teorias restringem-se a uma destas esferas, como ocorre com a teoria da 
justiça política de Robert Dahl. Outras priorizam uma esfera, explicando as demais a partir da considerada mais relevante, como pretende Marx ou os libertários ao enfocar a esfera econômica. Outras, ainda, apresentam visões mais abrangentes, como as de Michael Walzer e John Rawls.

A análise marxista é anticontratualista, historicista e por isso poderia parecer estranho qualificar sua proposição como uma teoria da justiça abstrata. Para os propósitos deste artigo não se enfoca a maneira como as teorias são construídas (a partir de uma visão histórica, como faz Marx, ou, a partir de uma visão hipotética, como fazem os contratualistas em geral, a exemplo dos libertários e de John Rawls).

O ponto que interessa para distinção apresentada é que os "abstracionistas", no que toca à equidade, tem uma teoria com uma visão mais abstrata e abrangente que a dos casualistas.

Os abstracionistas utilizam uma teoria completa da justiça, que serve de visão não só para organizar as várias instituições políticas, econômicas e sociais, mas também para preencher as falhas e as insuficiências do ordenamento jurídico.

As teorias abstracionistas atacam os pressupostos epistemológicos do positivismo jurídico ${ }^{4}$, para então evidenciar sua força normativa. ${ }^{5} \mathrm{Ou}$ seja, valem-se de uma estratégia argumentativa um pouco diferente dos

\footnotetext{
${ }^{4} \mathrm{O}$ positivismo jurídico, embora não se apresente com uma única feição, tem pressupostos comuns, como afirma Danilo Zolo: "É, portanto, antes de tudo, necessário que as leis não sejam secretas e que os enunciados normativos sejam formulados claramente e não dêem lugar a antinomias." (ZOLO, 2006, p. 40). Estes pressupostos serão apresentados a seguir. Cabe anotar, porém, uma diferença substancial entre o positivismo jurídico novecentista tradicional (especialmente da Escola da Exegese francesa), que considera a codificação como um objeto científico: “(...) formalmente válido, que pode ser encerrado, de modo relativamente simples, na definição de direito positivo.” (PALOMBELA, 2005, p. 125), do positivismo jurídico kelseniano. A vertente novecentista, para impedir a dissolução de seu objeto pela interpretação jurisprudencial: “(...) se faz defensora de uma tarefa de aclaramento (textual) da lei e executa a atividade interpretativa cognitiva (e não de vontade ou decisão), isenta de qualquer discricionariedade." (PALOMBELA, 2005, p. 126). Diferentemente, para Kelsen, a determinação do conteúdo de uma regra nunca é completa. Daí sua crítica: "A idéia, subjacente à teoria tradicional da interpretação, de que a determinação do ato jurídico a pôr, não realizada pela norma jurídica aplicanda, poderia ser obtida através de qualquer espécie de conhecimento do Direito preexistente, é uma auto-ilusão contraditória, pois vai contra o pressuposto da possibilidade de uma interpretação." (KELSEN, 2003, p. 392-3). Decorre desta crítica a assertiva de que: "A interpretação feita pelo órgão aplicador do Direito é sempre autêntica. Ela cria Direito." (KELSEN, 2003, p. 394). Esta "criatividade”, porém, não se confunde com o conceito de equidade tratado neste texto. Embora Kelsen afaste-se da corrente novecentista ao afirmar a possibilidade de interpretação judicial plural de conceitos jurídicos abertos, ele insiste que tal ideal (de certeza do direito) é "realizável aproximativamente". E tal aproximação pressupõe que o positivismo é capaz de construir: "(...) uma moldura dentro da qual existem várias possibilidades de aplicação, pelo que é conforme ao Direito todo o ato que se mantenha dentro deste quadro ou moldura, que preencha esta moldura em qualquer sentido possível." (KELSEN, 2003, p. 390). Mas, a equidade parte de problemas para os quais não existem exatos contornos na moldura, ou, que, simplesmente não podem ser resolvidos a partir do interior da moldura.

${ }_{5}^{5}$ Evitaremos utilizar o termo "pós-positivista" em razão da sua insuficiência. "Pós-positivista" dá a impressão de que o positivismo jurídico (na vertente kelseniana) estaria superado, o que não é necessariamente verdadeiro, apesar dos limites de uma teoria do direito dessa natureza, notadamente quanto aos critérios para a solução de casos difíceis para os quais não se encontra uma prédefinição na moldura do Direito. Por seu turno, o termo é impreciso na medida em que enquadra como "pós-positivismo" todos aqueles que, em alguma medida, criticam a validade incondicional do positivismo lógico-jurídico. Ocorre que os autores "pós" são muito diferentes entre si. Uns são apenas críticos e não apresentam qualquer prognóstico para o problema que encontram. Outros são propositivos e adotam uma posição radical de superação do positivismo jurídico, ao passo que outros aceitam dialogar, em alguma medida, com o modo de compreender as instituições do positivismo. Os "pós" ainda se dividem em liberais, igualitários, republicanos, utilitaristas, feministas, dentre outros, que apresentam propostas opostas para a solução do problema.
} 
casualistas $^{6}$, como se evidenciará a seguir, para demonstrar a necessidade de complementação do ordenamento jurídico.

O positivismo jurídico tradicional tem como pressupostos, para a validação da sua interpretação, a imparcialidade e a neutralidade do intérprete que apresentará a solução reclamada no caso concreto. Pressupõem também a possibilidade de delimitar adequadamente os institutos jurídicos, classificá-los e indicar sua natureza, de maneira que se empregue o método dedutivo para chegar à regra aplicável ao caso.

Atrelada a estes pressupostos está a pretensão de se ter uma "linguagem técnica", que permita enunciar cada conceito com apenas um sentido, de maneira que para cada situação concreta exista apenas uma resposta jurídica possível, ou, ao menos, como afirma Kelsen, que se delimite uma moldura, na qual as interpretações (significações) de conceitos abertos sejam validadas, o que seria feito por meio do: “(..) confronto de todas as outras normas da lei ou da ordem jurídica."(KELSEN, 2003, p. 391).

Os abstracionistas, como sobredito, apontam a necessidade de complementação do ordenamento jurídico a partir dos limites epistemológicos do positivismo.

Em casos difíceis, dizem os abstracionistas, o intérprete, mesmo sendo imparcial, não consegue ser neutro. ${ }^{7}$ Qual conceito de dignidade da pessoa humana deve ser utilizado para aplicar a pena a alguém que praticou um crime hediondo? Este é o mesmo conceito utilizado para interpretar a validade da cláusula de um contrato de adesão? Qual o conceito de "função social" deve ser utilizado para analisar um contrato entre pessoas que estão num mesmo patamar de renda? Tal conceito seria interpretado da mesma maneira numa relação em que uma das partes é uma instituição financeira, ou, o Estado? Como afirma Zagrebelsky: "(...) detrás del linguaje de los derechos se esconden significados, aspiraciones, ideales y concepciones de la vida social profundamente distintos.”(ZAGREBELSKY, 2011, p. 88), razão pela qual se deve rechaçar: “(..) la ideia de tratar cientificamente el derecho actual al estilo de una disciplina lógico-formal."(ZAGREBELSKY, 2011, p. 122).

Outra dificuldade interpretativa refere-se à pluralidade de métodos que podem ser empregados para a construção de uma decisão justa. Não só a dedução, mas, a indução e tantos outros mecanismos de construção do conhecimento podem auxiliar o intérprete. E, métodos diferentes podem ensejar soluções diferentes para casos

\footnotetext{
${ }^{6}$ Os casualistas procuram evidenciar a incompletude do direito a partir de três hipóteses verificáveis concretamente: a) singularidade do caso concreto; b) catástrofe que altere a situação de normalidade na qual seria aplicada a regra; c) evolução do sentimento moral da sociedade (PERELMAN, 1996, p. 163).

7 Toma-se o conceito de imparcialidade no sentido processual. A imparcialidade refere-se à atuação do magistrado que não (des)favorece esta ou aquela parte num litígio pelo simples fato de ter algum sentimento positivo ou negativo que possa interferir na decisão. A neutralidade refere-se à tentativa de se ignorar a experiência de vida e as concepções morais, religiosas e filosóficas, as quais não devem afetar o resultado o julgamento. Em casos mais simples os magistrados são neutros e imparciais. No entanto, em casos difíceis (aqueles nos quais se recorre à equidade), embora o magistrado consiga ser imparcial, dificilmente será neutro.
} 
idênticos ${ }^{8}$.

Do mesmo modo, a abertura, e a consequente insuficiência da linguagem jurídica (especialmente aquela dos valores e princípios que fundamentam a Constituição) exigem do intérprete um esforço hermenêutico que muitas vezes não é mitigado pela existência de regras constitucionais ou infraconstitucionais. Além disso, a depender do contexto histórico, social, econômico e político do intérprete, a concretização desta linguagem aberta pode ser radicalmente oposta à de outra pessoa situada num outro contexto, ou com compreensões valorativas diferentes.

Também por consequência desses desafios, a classificação, categorização e delimitação dos institutos jurídicos se torna mais difícil. Como qualificar um direito social relacionado à saúde? Será um direito fundamental (exigivel prontamente), ou, apenas uma expectativa de direito dependente de programas governamentais limitados por recursos públicos? ${ }^{9}$

Um exemplo interessante, que ainda desafia a racionalidade jurídica, diz respeito ao princípio de "proibição de retrocesso" quanto aos direitos fundamentais. A depender de quais direitos são considerados fundamentais, e, dos custos econômicos necessários a mantê-los, ter-se-á uma nítida tensão na interpretação do conceito de dignidade da pessoa. O direito a um tratamento de saúde pode ser qualificado como "mínimo existencial” (um direito fundamental, necessário à concretização da dignidade da pessoa humana), mas, também pode amoldar-se ao conceito da "reserva do possível", de maneira que sua concretização somente ocorrerá na existência de recursos públicos. Tal polêmica mostra que a concretização da "dignidade da pessoa humana”, que fundamenta a "proibição de retrocesso", pode ser interpretada de maneiras diversas, a depender das convicções (visão de justiça) do intérprete. Para os que qualificam este direito social como fundamental, afirmarão que o Poder Público está obrigado a assegurar o tratamento de saúde, mesmo em situações de crise econômica, sob pena de se malferir o princípio da "proibição de retrocesso". Já os que qualificam tal tratamento como expectativa de direito afirmarão que, a depender das condições econômicas, o tratamento poderá ou não ser assegurado, não havendo que se falar em retrocesso.

Nesse sentido, o que os abstracionistas procuram mostrar é que estes conceitos abertos da ordem jurídica (ex: dignidade da pessoa humana; função social dos contratos e da propriedade; etc.), para serem

\footnotetext{
${ }^{8}$ Nesse sentido, é ilustrativa a afirmação de Zagrebelsky: "El pluralismo de métodos es um rasgo essencial de nuestra cultura jurídica. Esto se mostra com claridade desde la 'escuela histórica', em cuya teoria de la interpretación confluían la gramática y la sintaxis, la lógica, la história y el sistema. A tales critérios se añaden hoy otros, como la comparación de los princípios jurídicos, consecuencia tanto de la aproximación entre los derechos como de la creación de um nuevo derecho común, o el análisis económico del derecho, que introduce entre los datos a tomar em consideración en la aplicación de las normas jurídicas el cálculo de la relación entre costes y benefícios y las consecuencias redistributivas del producto social." (ZAGREBELSKY, 2011, p. 134-5).

${ }^{9}$ Outros exemplos podem ser ilustrados nos recentes reposicionamentos do direito público e do direito privado. Cada vez mais fala-se em constitucionalização do direito privado, especialmente o direito de família. Do mesmo modo, ao discutir-se o princípio
} 
interpretados de maneira consistente e organizada devem encontrar seu fundamento em teorias da justiça. Sem este anteparo argumentativo não é possível ter uma visão coerente de uma Constituição, e, por conseguinte, de um ordenamento jurídico.

Perceba-se que estes autores abstracionistas também pressupõem a falibilidade do direito positivado, porém, poucos deles assumem a possibilidade de insuficiência das teorias (da justiça) propostas. Ou seja, os abstracionistas, assim como os positivistas creem na perfeição de um sistema normativo, com a diferença que os primeiros se amparam numa teoria da justiça, que não é legislada, tampouco submetida ao voto da maioria, tratando-se de uma formulação intelectual, ao passo que os segundos acreditam na possibilidade da perfectibilidade das regras postas.

Aqui surge outra questão. É que vários abstracionistas não tomam a segurança jurídica do ordenamento como um elemento importante para a justiça, ou seja, princípios como a separação de poderes, a preservação das expectativas legítimas ou a força dos precedentes não são levados a sério, a exemplo, do que ocorre com as proposições revolucionárias de tom marxista, ou mesmo, o que se dá com as propostas de ativismo judicial mais radical, similar à guardiania descrita por Robert Dahl. ${ }^{10}$

Como estas teorias da justiça são constructos intelectuais, portanto, sem uma validação externa ${ }^{11}$, muitas vezes intolerantes às correntes opositoras e sujeitas a polêmicas de vários níveis (do mais teórico ao mais prático), desconfia-se que elas não devem ser utilizadas na sua integralidade.

De toda forma, não se pode ignorar a existência de alguns exemplos interessantes de sua aplicação pelo Supremo Tribunal Federal.

Para relativizar o critério normativo de miserabilidade, que autoriza a concessão de benefício assistencial, o Min. Marco Aurélio, no julgamento do Recurso Extraordinário n. ${ }^{\circ}$ 567.985/MT, valeu-se da teoria da "justiça como equidade" de John Rawls, bem como da teoria do discurso de J. Habermas:

Ora, a eliminação dessa forma aguda de pobreza é pré-condição da construção de uma sociedade verdadeiramente democrática, da estabilidade política, enfim, do desenvolvimento do país como um todo. Sem condições materiais, não pode haver um cidadão pleno, apto a participar nos debates públicos, a produzir argumentos e críticas. Se há algum consenso no âmbito da filosofia moral, é a respeito da existência do dever do Estado de entregar um

da eficácia e da eficiência no direito administrativo, procura-se empregar, cada vez mais, conceitos da esfera privada à atuação do Estado. Esta crise de delimitação jurídica decorre, em parte, da generalidade da linguagem, dos princípios e valores da Constituição.

${ }^{10}$ A Guardiania tem pressupostos polêmicos, pois assume que: “(...) somente um grupo de pessoas altamente qualificadas - ou seja, os guardiões - pode ser racionalmente considerado capaz de possuir tanto o conhecimento quanto a virtude necessários para servir ao bem de todos os que estão sujeitos às leis." (DAHL, 2012, p. 83) Nesse sentido, os guardiões não precisariam justificar suas posições, ainda que (eventual e aparentemente) contraditórias, porque seriam presumidamente mais preparados para governar (e decidir sobre o que é justo) do que as demais pessoas.

${ }^{11}$ As teorias da justiça não são votadas democraticamente, não são impostas por uma autoridade superior (estatal ou divina). Sua força é estritamente racional. Sua aceitação depende de um consenso racional de difícil concretização. Para ilustrar tal dificuldade basta recordar as polêmicas que envolvem a visão marxista e a neoliberal de direita sobre a responsabilidade e a sanção no direito penal. Ao passo que a primeira tende a mitigar o conceito de responsabilidade e as penas, a segunda propõe o contrário. 
conjunto de prestações básicas necessárias à sobrevivência do indivíduo, reconhecida tanto pelos defensores do liberalismo, entre os quais se destaca John Rawls (Liberalismo político, 1999, pp. 32-33), como por aqueles que extraem os direitos fundamentais da teoria do discurso, caso de Jürgen Habermas (Direito e democracia entre facticidade e validade, v. I, 2006, pp. 159-160). Mesmo os que defendem a integração maior entre o Direito e a comunidade, conferindo a este papel preponderante na definição dos limites dos direitos fundamentais, não escapam a essa compreensão. (p. 7 do acórdão).

A declaração de constitucionalidade das cotas sociais e raciais para o acesso ao ensino superior nas universidades públicas (ADPF n. ${ }^{\text {186/DF }) ~ t a m b e ́ m ~ u t i l i z a ~ d e ~ p a r t e s ~ d e ~ t e o r i a s ~ d a ~ j u s t i c ̧ a, ~ c o m o ~ a ~ d e ~ J o h n ~ R a w l s ~ e ~}$ Ronald Dworkin, para afastar a ideia de igualdade formal do art. $5^{\circ}$, caput, da Constituição mostrando que existem outros sentidos possíveis para a igualdade (substancial, material, de oportunidades, etc.). O mesmo vale para a ADPF n. ${ }^{\circ}$ 54/DF do STF, na qual se analisou a possibilidade de interrupção da gravidez no caso de feto anencéfalo, valendo-se de argumentos teóricos importantes da teoria da justiça de Dworkin.

Outros exemplos poderiam ser apresentados, ainda que implicitamente, como aqueles extraídos dos votos dos Ministros do STF, que declararam a inconstitucionalidade do financiamento de campanhas eleitorais por pessoas jurídicas (ADI n. 4650 do STF) ${ }^{12}$, ou mesmo a interpretação do Min. Eros Grau nos Habeas Corpus n. ${ }^{\circ} 84.078$ e 95.009, nos quais se apresenta um conceito de liberdade individual similar ao primeiro princípio e justiça de John Rawls.

Tais casos mostram que as cláusulas abertas da Constituição podem assumir diversos sentidos, porque os intérpretes não são neutros, porque utilizam métodos, categorias e formas de raciocinar que levam a soluções diferentes.

Embora sejam interessantes, estes exemplos não são suficientes para demonstrar a integral validade da utilização de teorias da justiça para fundamentar a decisão em casos difíceis.

É que a interpretação de princípios de justiça pode conduzir a situações polêmicas e acarretar distorções interpretativas de outros valores e princípios da ordem jurídica ${ }^{13}$. Na verdade, quanto a este ponto, há um risco similar ao da vertente casualista, no sentido de uma teoria da justiça poder hiperdimensionar um valor jurídico em detrimento de outro. Com isso, ter-se-á a dificuldade de sanar conflitos interpretativos invalidando opções valorativas inscritas na Constituição. Como se diz usualmente é necessário interpretar todos os valores constitucionais de maneira harmônica. Ocorre que tal harmonia, muitas vezes, ocorre por meio da priorização de um princípio ou valor em detrimento de outro, que permanecerá em segundo plano (ao menos, num caso

\footnotetext{
${ }^{12}$ Tanto John Rawls, quanto Ronald Dworkin propõem princípios de justiça para a limitação do financiamento de campanhas, para a assegurar a igualdade de chances na disputa eleitoral. Como o financiamento por empresas acaba por favorecer, de maneira desarrazoada, uma candidatura, pode-se extrair das referidas teorias a justificativa para sua utilização com pano de fundo argumentativo.

${ }^{13}$ Alexy distingue princípio de valor, afirmando que o primeiro é deontológico (dever-ser) e o segundo axiológico (no âmbito do bom), de maneira que para o direito importa o primeiro (ALEXY, 2011, p. 153). A distinção é pertinente no interior da teoria do
} 
concreto).

As teorias da justiça trazem uma priorização explícita e organizada destes princípios e valores. Ocorre que os princípios e valores inscritos na ordem jurídica não trazem esta priorização, o que faz recair sobre as teorias da justiça a suspeita de que elas não podem ser empregadas sem maiores cuidados. Noutros termos, ao adotar-se uma teoria da justiça, sem qualquer restrição, corre-se o risco de não só engessar a solução de casos concretos (que podem apresentar feições diferentes e trazer sérios constrangimentos à aplicação da teoria), mas, de se emprestar muito peso a certos princípio e valores constitucionais em detrimento de outros.

Para exemplificar tais dificuldades, tome-se o caso do princípio da moralidade e a regra da anualidade (decorrente do princípio da segurança jurídica), os quais foram invocados na decisão sobre a aplicabilidade

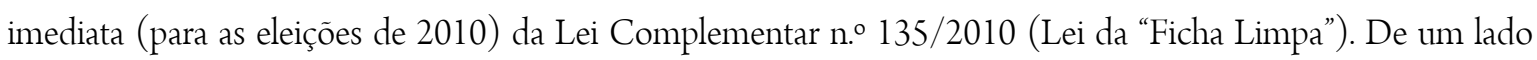
afirmava-se ser justo dar concretude à probidade administrativa de forma imediata, ao passo que a tese vencedora era de que a segurança jurídica (da regra da anualidade) deveria prevalecer. A tensão "justiça x segurança jurídica” revelou sua força no referido julgamento, de maneira que o anseio pela justiça foi mitigado em face da cláusula constitucional de segurança. Noutros termos, o STF, por maioria, limitou a extensão do conceito de "moralidade" à regra do art. 16 da Constituição. ${ }^{14}$

Em que pese as teorias da justiça apresentarem um cenário organizado de princípios e valores, não há qualquer garantia de que elas possam ser aplicadas, recorrentemente, em casos difíceis. Na verdade, sequer há consenso sobre quais teorias são mais ou menos compatíveis e adequadas a uma Constituição. Perceba-se que a dificuldade não diz respeito somente ao fato de existirem Constituições diferentes ${ }^{15}$, mas às divergências sobre as formas de organizar e priorizar os princípios e os valores para uma Constituição justa.

Normalmente, o ônus de se utilizar esta ou aquela teoria da justiça para organizar um sistema de justiça política, econômica e social, nos Estados Ocidentais Modernos, é entregue ao legislador, legitimado democraticamente. ${ }^{16}$ No entanto, nem sempre o legislador se desincumbe deste dever adequadamente, o que

autor. No entanto, considerando que não há consenso sobre a necessidade desta distinção, será mantida utilização de princípios e valores para referir-se aos casos de colisão em casos difíceis.

14 “Art. 16. A lei que alterar o processo eleitoral entrará em vigor na data de sua publicação, não se aplicando à eleição que ocorra até um ano da data de sua vigência."

${ }^{15}$ As Constituições ocidentais modernas têm estruturas principiológicas similares, de maneira que as divergência mais significativas entre as teorias da justiça e as teorias da constituição não estão no objeto (Constituição), mas, na própria forma de organizar e priorizar valores e princípios.

${ }^{16}$ Muitas regras (especialmente aquelas não protegidas por cláusula pétreas) apresentam pontos de arbitrariedade, na medida em que não foram pensadas para a resolução de todos os casos concretos. É o caso, por exemplo, do homem que, apesar de ter uma posição de total respeito com a mulher, não pode participar de um concurso público para ocupar a função de carcereiro numa penitenciária feminina. A razão da discriminação da regra é a história dominação masculina. Este homem, certamente, não faz parte do histórico de discriminação, e, nesse sentido, a regra, sob sua ótica, parece injusta. No entanto, a regra é pensada a partir de um contexto mais abrangente, de maneira que ela continuará válida (apesar de não atender ao interesse desse homem). Perceba-se que a regra não ofende o direito constitucional deste homem de realizar concursos, porquanto as demais carreiras estão abertas a ele. Logo, não há uma inconstitucionalidade na discriminação. Por essa razão, a regra continuará sendo aplicada, enquanto não 
enseja a aplicação da equidade por outras esferas do poder. O problema é que o intérprete, ao decidir o caso concreto, não tem como convocar um plebiscito, um referendo ou realizar uma consulta pública para se desincumbir deste ônus. Ou seja, permanecerá com o intérprete o ônus jurídico/político de escolher uma das teorias da justiça para interpretar o caso difícil, isso sem que exista, no atual momento do desenvolvimento da hermenêutica, uma possibilidade definitiva de se alcançar um consenso sobre qual teoria deve ser empregada.

O presente artigo busca indicar alguns procedimentos para equacionar tal dificuldade. Assim, no próximo tópico, será apontada a justificativa do porquê se utilizar da corrente abstracionista com ponto de partida (preparação) para a ponderação, bem como o procedimento razoável para aplicar-se uma teoria da justiça na solução de um caso concreto.

\section{DEFINIÇÃO DE UM PONTO DE PARTIDA RAZOÁVEL PARA O PROCEDIMENTO ARGUMENTATIVO}

Não há um consenso sobre quais critérios devem balizar a construção e a aplicação de soluções equitativas. Tampouco, é possível pré-determinar qual das vertentes (casualista ou a abstracionista) deverá ser utilizada como ponto de partida para a ponderação. ${ }^{17}$

Apesar dessas dificuldades e tensões, não se pode dizer que as escolhas do intérprete são radicalmente arbitrárias, isto porque: 1) ao utilizar uma das correntes, devem-se seguir procedimentos argumentativo-racionais que orientam e limitam as escolhas; logo não há liberdade, mas, discricionariedade (limitada) para escolher entre as correntes e os tipos de argumentação racional a serem empregadas; 2) o objetivo final é tornar compreensível o julgamento de casos difíceis.

O ponto de partida sugerido neste artigo consiste em vincular a equidade ao conceito de "razoabilidade", diferenciando-a do conceito de "racionalidade" (como instrumental estratégico e parcial). Antes, porém, de

estiverem presentes as hipóteses de aplicação da equidade, e, a única saída para as pessoas que defendem estes interesses minoritários será a via política da reforma legislativa. Não havendo sensibilização da maioria, persistirá a limitação do comando normativo existente. Note-se que este não é um problema a ser resolvido por meio da equidade, a não ser que se demonstrem suas hipóteses de aplicação, seja a partir dos argumentos dos casualistas, seja a partir dos argumentos do abstracionista. Não sendo possível se desonerar de tal ônus, a solução jurídica ao caso dos interesses minoritários será a tradicional: aplica-se a regra, a não ser que ela seja inconstitucional, ou, que seja modificada pelo Poder Legislativo.

${ }^{17}$ Como alerta Palombela: "(...) a busca da 'eqüidade na aplicação do direito e a consciência do papel criativo dos juízes e da eqüipolência da lei e dos direitos desmantelam o mito da rigidez formal do direito e exigem uma adequação dele aos casos; mas isso cria uma tensão permanente entre exigência de estabilidade e exigência de flexibilidade do direito, por um lado, enquanto, por outro, impõe a coordenação entre direito como portador de ordem funcional, sistêmica, reguladora e organizativa e o direito entendido como expressão e fiador das convicções morais, de valores partilhados, de conteúdos específicos de justiça, de direitos subjetivos e de declarações de princípios assumidas agora, inclusive no plano jurídico, como 'universais'. Tal tensão está longe de ser resolvida e não pode provavelmente ser resolvida por uma teoria do direito (e muito menos por uma teoria do raciocínio jurídico). Exige a elaboração de uma reflexão mais consistente sobre os institutos da democracia contemporânea e sobre seu funcionamento, sobre as 'regras' próprias de uma sociedade complexa, sobre as necessidades de uma nova dogmática, sobre a funções do direito." (PALOMBELA, 2005, p. 343-4) 
desenvolver tal vinculação e apresentar o indicativo de como a "razoabilidade" funcionará, a partir da vertente abstracionista, como um instrumento para a interpretação do caso difícil, impõe-se algumas observações inicias, a seguir apresentadas.

\section{Justificativa para a adoção de um conceito de razoabilidade}

A razoabilidade se associa a vários conceitos distintos, o que dificulta a sua determinação conceitual. ${ }^{18}$

Zagrebelsky, por exemplo, afirma que a razoabilidade é uma atitude, uma predisposição do intérprete para:

“(...) soluciones dúctiles que tomen em consideración todas las razones que puedan reivindicar buenos princípios em su favor. (...) Busca la respuesta más adecuada para las expectativas legítima y, por ello, está abierto al enfrentamiento entre todas las posiciones que remite a princípios vigentes em el derecho.

(...)

Es razonable la categorización de los hechos que toma em cuenta todos los princípios implicados; es razonable la regla, individualizada em el marco de las condiciones limitadoras del derecho como ordenamiento, que responde a las exigencias del caso. Em la búsqueda de esta 'razonabilidad' de conjunto consiste la labor de unificación del derecho que tiene asignada como tarea la jurisprudência." (ZAGREBELSKY, 2011, p. 123; 147-8).

Nesse sentido, a razoabilidade figura como um mandamento de prudência e de flexibilidade tanto na identificação do critério que constitui a regra, quanto na solução do caso concreto (ZAGREBELSKY, 2011, p. 123), exigindo: 1) a consideração de todas as razões que podem reivindicar bons princípios; 2) a busca pela resposta mais adequada para as expectativas legítimas; 3) a abertura à ponderação frente ao inevitável conflito com outros princípios; 4) a tentativa de unificar o direito considerando: "Ias exigencias de justicia substantiva materializadas em los casos que han de ser resueltos juridicamente."(ZAGREBELSKY, 201 1, p. 148).

Os "bons princípios" seriam a igualdade, a liberdade, a justiça, a solidariedade, a pessoa e a dignidade humana (ZAGREBELSKY, 2011 p. 124), todavia, a determinação de seu conteúdo e a sua hierarquização são questões que permanecem em aberto e somente podem ser determinadas no caso concreto. A par desta dificuldade, Zagrebelsky afirma a necessidade da ponderação que promova um equilíbrio entre os bens jurídicos por meio da "otimização" de princípios (ZAGREBELSKY, p. 125), o que aproxima o seu conceito de "razoabilidade" ao de "proporcionalidade" na versão de Alexy. ${ }^{19}$

\footnotetext{
${ }^{18}$ Além das divergências a seguir exemplificadas, há outra polêmica sobre a designação (natureza) da razoabilidade ora como princípio, ora como postulado, ora como mandamento para a interpretação, ora como procedimento racional justificador de critérios e princípios de justiça. A discussão é extensa e não será aprofundada nesta oportunidade, já que a própria compreensão do conceito de "razoabilidade", ainda que tratada como sinônimo de "proporcionalidade" ou aproximado de outros termos como "igualdade", "prudência", "consistência", "congruência, etc., já indicam, ainda que implicitamente, o sentido (natureza) que cada autor a ela atribui.

${ }^{19}$ Nesse sentido, afirma Alexy: "Princípios são (...) mandamentos de otimização, que são caracterizados por poderem ser satisfeitos em graus variados e pelo fato de que a medida devida de sua satisfação não depende somente das possibilidades fáticas, mas também das possibilidades jurídicas."(ALEXY, 2011, p.90).
} 
Humberto Ávila tenta distinguir a razoabilidade da proporcionalidade, da igualdade, do mandamento de proibição de excesso, procurando assentar um conceito autônomo a partir de três acepções:

"Primeiro, a razoabilidade é utilizada como diretriz que exige a relação das normas gerais com as individualidades do caso concreto, quer mostrando sob qual perspectiva a norma deve ser aplicada, quer indicando em quais hipóteses o caso individual, em virtude de suas especificidades, deixa de se enquadrar na norma geral. Segundo, a razoabilidade é empregada como diretriz que exige uma vinculação das normas jurídicas com o mundo ao qual elas fazem referência, seja reclamando a existência de um suporte empírico e adequado a qualquer ato jurídico, seja demandando uma relação congruente entre a medida adotada e o fim que ela pretende atingir. Terceiro, a razoabilidade é utilizada como diretriz que exige a relação de equivalência entre duas grandezas." (ÁVILA, 2007, p. 152).

Em que pese o esforço em decompor a razoabilidade para mostrar sua autonomia frente a outros termos, o fato é que as acepções apresentadas por Ávila ora se aproximam das hipóteses nas quais se justifica o afastamento da lei e do procedente (PERELMAN, 1996, p. 163), ora das três máximas parciais da adequação, da necessidade e da proporcionalidade em sentido estrito (ALEXY, 2011, p. 118 e 176-7). ${ }^{20}$ Como se percebe, há considerável dificuldade em constituir um conceito autônomo para "razoabilidade" e a polêmica parece estar longe de ser resolvida. ${ }^{21}$

A despeito da indeterminação do conceito de "razoabilidade" é possível sugerir alguns traços comuns entre as várias análises anteriormente apresentadas, ao vinculá-la ao conceito de "equidade". É razoável (e equânime) afastar-se da lei ou do precedente nas hipóteses de insuficiência do positivismo, conforme se demonstrou no início do artigo. Também é razoável (e equânime) constituir uma solução adequada ao caso concreto que considere, prudentemente, todos os argumentos contrapostos e que seja capaz de promover um consenso racional/justificado sobre a melhor solução para o caso difícil. Este é o aspecto que será desenvolvido a seguir.

\section{Razoabilidade como forma de pensar a aplicação da equidade}

Como afirmado inicialmente, o ponto de partida sugerido neste artigo consiste em vincular a equidade

\footnotetext{
${ }^{20}$ A razoabilidade como equidade aproxima-se das hipóteses a que refere Perelman (1996, p. 163). A razoabilidade como congruência refere-se às possibilidades fáticas de concretização do princípio, aproximando-se das máximas da adequação e da necessidade (mandamento do meio menos gravoso). A razoabilidade como equivalência, em menor medida, está compreendida na máxima parcial da proporcionalidade em sentido estrito (mandamento de sopesamento propriamente dito) (ALEXY, 2011, p. 118 e 176-7).

${ }^{21}$ Sobre as maneiras de se conceituar a razoabilidade, leia-se o seguinte comentário: "Há, na doutrina nacional, um debate relevante sobre a existência de possíveis diferenças entre os princípios da proporcionalidade e da razoabilidade. Um expressivo segmento de juristas, em que se incluem autores como Gilmar Ferreira Mendes, Luís Roberto Barroso, Suzana de Toledo Barros e Fábio Corrêa Souza de Oliveira, afirma que tais princípios seriam equivalentes, apesar da origem histórica diversa - a proporcionalidade originária do direito alemão, e a razoabilidade do anglo-saxão. Outros autores, como Willis Santiago Guerra Filho, Virgílio Afonso da Silva, Humberto Ávila, José Adércio Leite Sampaio e Wilson Steinmetz, negam esta equivalência, atribuindo conteúdos diferentes à razoabilidade, que não se basearia nos três subprincípios em que se divida a proporcionalidade. " (SOUZA NETO, SARMENTO, 2012, p. 483).
} 
ao conceito de "razoabilidade", contrapondo-o ao de "racionalidade". Tal estratégia almeja: a) apresentar a "razoabilidade" como uma forma "qualitativa" para ponderação de princípios e valores, diferindo-a de análises "quantitativas" que atribuem pesos numéricos a argumentos e princípios (ALEXY, 2011, p. 162) 22 ; b) distanciarse das distinções "razoabilidade/proporcionalidade”, "razoabilidade/igualdade”, porque elas tendem a incorrer nas dubiedades conceituais anteriormente comentadas ${ }^{23}$; c) indicar uma forma de promover o equilíbrio e a ponderação de argumentos a partir de teorias/princípios de justiça, procurando identificar quais deles tendem a promover justificativas menos arbitrárias para os critérios que nortearão a solução do caso concreto ${ }^{24}$.

A distinção entre "razoável" e "racional" não é nova ${ }^{25}$ e daí poderia surgir outra polêmica sobre qual concepção utilizar. Neste artigo adotar-se-á distinção feita por John Rawls ${ }^{26}$, o qual propõe que a razoabilidade funciona como a forma de reflexão norteadora da equidade, ao passo que a racionalidade conduz à interpretação

\footnotetext{
22 A proporcionalidade em sentido estrito pode ser pensada tanto sob uma perspectiva qualitativa, como propõe Alexy (2011, p.165), quanto sob uma perspectiva "quantitativa". Nesse último caso, não há dificuldades para a aplicação da regra ao caso concreto, posto que o grau de intensidade de sua incidência está satisfatoriamente determinada pela regra. Ou seja, não se trata de uma hipótese de colisão de princípios, pois colisão não há. Um exemplo ilustrará o argumento. Suponha-se que um estudante "A" não obteve a nota semestral mínima (7,0) para ser aprovado, pois obteve a nota 5,0, ao passo que "B" obteve 6,0. Ambos farão a prova final. Pergunta-se: ambos deverão alcançar a mesma nota para serem aprovados? Esta ponderação tem um elemento qualitativo, pois, opõe o princípio da igualdade formal (ambos não foram aprovados) ao do (de)mérito. Caso opte-se por atribuir maior importância ao princípio meritório, a conclusão será de que o aluno com menor média deverá esforçar-se mais. Uma fórmula que determinasse o grau de intensidade de esforço (proporcional) exigiria que obtivessem nota mínima igual ou superior àquela que resultasse de uma operação na qual se tomasse a nota 10,0 como base de cálculo, da qual se descontaria a média semestral de cada estudante. Ou seja, para ser aprovado, "A" deve alcançar a nota 5,0 (10 - 5) e "B" a nota 4,0 (10 - 6). A metrificação (quantificação), segundo o critério "mérito” não se mostra problemática. A metrificação, porém, é arbitrária, como afirma Alexy (2011, p. 161-2), quando se refere à ponderação qualitativa, ou seja, na qual existe a colisão de princípios. A quantificação de um princípio pressupõe um juízo arbitrário sobre o peso (numérico) atribuído ao princípio, que se reproduz na solução definitiva.

${ }^{23}$ Conforme se evidenciará doravante, a "razoabilidade" no sentido aqui apresentado, aproxima-se das máximas parciais enunciadas por Alexy (adequação, necessidade e proporcionalidade em sentido estrito). No entanto, é mais abrangente, no sentido de que investiga o momento de "preparação da ponderação" ao analisar os argumentos das teorias de justiças concorrentes, e mais abstrata, por trabalhar com princípios de justiça (e não somente com as regras de colisão). Nessa linha de argumentação, a "razoabilidade", por se mais abrangente e abstrata, incorporaria a proporcionalidade (no sentido qualitativo). Com isso ter-se-iam dois modelos de aplicação de regras, um positivista (que compreende a proporcionalidade em sentido estrito-quantitativo), e um equitativo (por meio da razoabilidade, que congloba a proporcionalidade em sentido qualitativo). Tais classificações não são simétricas e perfeitas, mas, podem cumprir a função de esclarecimento sobre o quadro ora apresentado.

${ }^{24} \mathrm{~A}$ "razoabilidade", oposta, à "racionalidade" remete à ideia de que a primeira é imparcial e tende a produzir consenso, ao passo que a segunda é parcial e necessita do uso da força para obter a adesão das pessoas.

${ }^{25}$ Como afirma Audard: "Rawls is clearly inspired by a long tradition of politica philosophy (...)" (AUDARD, 2007, p. 38).

${ }^{26}$ A escolha deve-se ao fato de Rawls ser considerado um dos principais teóricos da justiça do século XX, além de apresentar um procedimento razoável para justificação de princípios (por meio do equilíbrio reflexivo de juízos promovidos a partir da figuração da posição original) que é, com alguns ajustes, empregada por vários autores que debatem sobre a justificação de princípios de justiça aplicáveis às sociedades democráticas. É inegável que as perspectivas de Zagrebelsky, Ávila e Alexy, em alguma medida, aproximam-se dos critérios discutidos por Rawls. No entanto, como destacado no tópico anterior, não é possível identificar, a partir da compreensão destes autores, um conceito de "razoabilidade" que se distinga da proporcionalidade. Já Rawls, ao distinguir o "razoável" do "racional" reposiciona a discussão, como procurar-se-á demonstrar a seguir, de maneira abrangente e abstrata. Com isso, obtém-se um campo próprio para o conceito de "razoabilidade" que figura como orientação procedimental para análise de teorias da justiça. Nesse sentido, ao menos quanto às premissas teóricas, Rawls distancia-se dos pensadores da argumentação como Alexy e Ávila.
} 
estratégica (e parcial) dos princípios e das regras jurídicas. ${ }^{27}$ Tal diferenciação está assim exemplificada por Rawls:

(...) creio ser possível diferenciar duas formas de razão prática. Podemos pensá-la como racional ou razoável. Por ora, 'racional' [rational] e 'razoável' [reasonable] são simples palavras ou rótulos, cuja diferenciação ainda não nos é conhecida. Na linguagem comum, ambos os termos se referem a algo que não apresenta contradições com a razão ou que se baseia na razão. Mas, ao usar esses termos no dia a dia, parece que percebemos, sim, a diferença entre eles. Geralmente, eles não são usados como sinônimos. Tome-se como exemplo a situação em que alguém diz: 'Beltrano usou uma tática muito agressiva de negociação, agindo de modo extremamente irrazoável; porém, é preciso admitir que esse comportamento, na perspectiva pessoal de Beltrano, foi perfeitamente racional.' Nessa frase é possível, de certa forma, reconhecer a diferença. Temos a tendência de usar 'razoável' para indicar uma mentalidade imparcial, ponderação, capacidade de perceber o ponto de vista dos outros etc.; 'racional', ao contrário, tem mais o sentido de agir de acordo com a lógica visando o próprio bem ou aos interesses pessoais. (RAWLS, 2012, p. 60)

Ainda como afirma o autor: "(...) é pelo razoável que entramos como iguais no mundo público dos outros e dispomo-nos a propor, ou aceitar, conforme o caso, termos equitativos de cooperação com eles." (RAWLS, 2000a, p. 97). Rawls também se refere ao termo "razoável”, no sentido de que: “(..) as pessoas são razoáveis no tocante aos outros [quando] estão dispostas a orientar sua conduta por um princípio a partir do qual elas e outras podem raciocinar conjuntamente; e as pessoas razóaveis levam em conta as consequências de suas ações sobre a felicidade dos outros."(RAWLS, 2000a, p. 92).

A razoabilidade não é apenas uma virtude do intérprete, mas, uma exigência da decisão equitativa ${ }^{28}$. Uma decisão equitativa deve ser razoável, no sentido de que se mostra convincente para qualquer pessoa capaz de ponderar a posição das demais pessoas afetadas pela decisão, e, ainda assim, justificar porque alguém (vencedor ou perdedor) deve aceitar o critério que fundamenta a regra proposta e, por conseguinte, o resultado do julgamento.

É por essa razão que o conceito de razoabilidade deve incluir: “(...) uma ideia de reciprocidade e de mutualidade.”(RAWLS, 2002b, p. 66). ${ }^{29}$ Não se ignora que Rawls, ao referir-se à "razoabilidade”, dirige-se, num

\footnotetext{
${ }^{27}$ John Rawls é um neo-kantiano e utiliza o "razoável” na construção hipotética de sua teoria. Ele não avança, por exemplo, sobre a maneira como a "posição original" (e a reciprocidade que ela supõe) poderia auxiliar os intérpretes em casos concretos difíceis. Estas questões estão abertas. De toda forma, neste texto, adapta-se a distinção entre razoável de racional de Rawls vinculando o razoável à forma como deve se raciocinar para construir uma solução equitativa num caso concreto.

${ }^{28}$ Como afirmam Souza Neto e Sarmento: "Esta exigência de razoabilidade, voltada para a ação de cada cidadão nas deliberações públicas, pode até ser um ideal a ser perseguido, mas, ela não tem como ser juridicamente imposta a cada indivíduo, sob pena de grave restrição às liberdades individuais como o próprio Rawls reconhece. Porém em relação ao Estado e à ação dos agentes públicos é diferente. A exigência de razoabilidade torna-se juridicamente exigível para limitar o uso da autoridade estatal, e envolve a necessidade de que cada ato dos poderes públicos estejam amparados por argumentos 'razoáveis', isto é, por argumentos que sejam aceitáveis por todos os cidadãos, por não se basearem em idiossincrasias, em interesses econômicos ou corporativos de grupos próximos aos governantes, ou em compreensões particulares de natureza religiosa ou filosófico dos detentores do poder." (SOUZA NETO, SARMENTO, 2012, p. 488)

${ }^{29}$ Sobre a relação entre mutualidade (como vantagem recíproca) e reciprocidade (como igual consideração), Audard esclarece que: "(...) the two aspects of practical reason, the Prudential or Rational and the Ethical or Reasoneable (PL: 48-54), are insperable but cannot be translated into the two concepts of mutual advantage and impartiality. Justice as reciprocity is the conception that, for him [Rawls], combines de Prudential value of cooperation whit the moral value of equal respect, of treating each other impartially." (AUDARD, 2007, p. 38).
} 
primeiro momento, às pessoas (fictícias) que atuam de maneira imparcial na posição original (espécie de contrato hipotético de sua teoria da justiça). No entanto, não se pode ignorar que os termos "reciprocidade" e "mutualidade" também tem aplicação concreta, ao oferecerem um ponto de vista prático para verificar em que medida uma proposição equitativa, realmente, leva a sério a posição de todas as pessoas afetadas pela decisão que se pretende construir. ${ }^{30}$ Ou seja, não se trata de estabelecer vantagens mútuas às partes, mas, de ponderar as propostas (das teorias da justiça) de maneira imparcial, aplicando-as às partes como se elas ocupassem todas as posições possíveis, seja as que as favorecem, seja as que as desfavorecem. A reciprocidade e a mutualidade, nesse sentido, exige que o intérprete pondere os argumentos das partes de maneira a ultrapassar a posição estratégica (parcial) que elas assumem, buscando-se com isso encontrar um critério (razoável) que possa ser utilizada para ambas.

Como sobredito, não existem critérios fixos e peremptórios para a aplicação da equidade, mas, a tentativa de encontrar um procedimento razoável (para a ponderação dos argumentos relacionados aos princípios e às teorias da justiça) pode tornar uma decisão equitativa mais justa. ${ }^{31}$

Dito de outra forma, o objetivo é mostrar, por exemplo, que num conflito entre direitos fundamentais, ou entre direitos fundamentais e interesses coletivos, a defesa da prioridade de uma liberdade frente ao Estado ou frente a outros indivíduos pressupõe uma compreensão mais ou menos organizada sobre o conceito, a função e a aplicação da liberdade e dos demais princípios e valores a serem considerados. Nesse sentido, o procedimento razoável que se pretende formular figura como uma "preparação à ponderação" como afirma Humberto Ávila:

"Nessa fase [da preparação da ponderação] devem ser analisados todos os elementos e argumentos, o mais exaustivamente possível. É comum proceder-se a uma ponderação sem indicar, de antemão, o que, precisamente, está sendo objeto de sopesamento. Isso, evidentemente, viola o postulado científico da explicitude das premissas, bem como princípio jurídico da fundamentação das decisões, ínsito ao conceito de Estado de Direito." (ÁVILA, 2007, p. 144).

Tal "preparação" envolve a justificação da escolha de qual acepção da equidade norteará a ponderação,

Esta ideia de reciprocidade também pode ser traduzida na igualdade de consideração e de respeito utilizada por Dworkin, ou ainda, em alguma medida, pelo conceito de igualdade substancial (material) empregada pelo STF, quando trata de questões polêmicas como as relacionadas a direitos sociais, a exemplo da travada no voto do Min. Dias Toffoli no Recurso Extraordinário n. ${ }^{\circ}$ $581.488 / \mathrm{RS}$.

${ }^{30}$ Nesse sentido: "Embora o autor não especifique qualquer método a ser seguido na fundamentação das decisões judiciais, confiando na capacidade individual do julgador para estabelecer a concepção de justiça política mais razoável dentro do marco legal vigente, indica a presença de um controle popular, através do debate instaurado a partir da interpretação dada a temas polêmicos que suscitem divergências ou desagrado. De todo modo, o caráter prescritivo e o viés distintivamente liberal de seu sistema de revisão judicial repousam no destacado acento conferido à exclusiva invocação dos valores políticos comuns que devem prevalecer sobre quaisquer outros tipos de apreciação, o que equivale, no limite e sentido inverso, à absoluta priorização e correlata proteção superlativa da autonomia moral dos cidadãos em relação ao âmbito de sua autodeterminação." (DOBROWOLSKI, 2009, p. 602)

${ }^{31}$ Neste artigo o conceito de "razoabilidade" é utilizado com duas finalidades: 1) escolher a vertente da equidade que será tomada como ponto de partida da argumentação (preparação da ponderação); 2) orientar a formulação do procedimento, a comparação entre teorias da justiça e a concepção dos testes que serão organizados no último tópico. 
ou seja, a maneira pela qual pode-se raciocinar sobre os princípios de justiça aplicáveis ao caso concreto.

Conforme se evidenciará a seguir o conceito de "razoabilidade" indica que a vertente abstracionista pode se constituir como um ponto de partida adequado para a análise dos princípios e valores incidentes/em conflito num caso difícil.

\section{A utilização da corrente abstracionista como ponto de partida razoável}

Apresentado o conceito de "razoabilidade" que irá conduzir a formulação do procedimento que levará à união entre algum princípio de justiça à regra que resolverá o caso difícil (ponderação), cabe agora questionar qual vertente da equidade deve ser utilizada como ponto de partida para a argumentação. ${ }^{32}$

A seguir será sugerida uma resposta ao seguinte questionamento: já que não há um ponto de partida incontroverso sobre a maneira de resolver os problemas jurídicos mais difíceis que demandam o uso da equidade, como deve o intérprete proceder para chegar a uma solução menos arbitrária?

A primeira intuição é de que não é possível tomar o ponto de partida dos casualistas, isto porque a equidade, como afirma Perelman, exige um auditório apropriado em que se possa construir argumentos imparciais para a solução do caso concreto; todavia, as decisões difíceis não são tomadas somente em Cortes, por órgãos colegiados; e se isso não bastasse, muitas questões dependem de conhecimentos e informações de caráter extrajurídico que não estão à disposição dos juristas; na maioria das vezes, decisões importantes e difíceis são tomadas por magistrados, administradores e servidores públicos na solidão de seus gabinetes, onde não há um foro democrático adequado para estabelecer o contraditório entre uma tese, uma antítese, e outras tantas proposições que poderiam ser apresentadas num “auditório universal”, como pretende Perelman.

Por exemplo: numa lide individual que envolve apenas duas partes é provável que os argumentos e informações por elas trazidos restrinjam-se aos pontos de vistas, visões, contextos e informações que elas vivenciam; ou, segundo seu interesse parcial, alguns argumentos serão manejados com o fim de convencer a autoridade que tomará a decisão, sem que exista qualquer compromisso com a razoabilidade da decisão a ser tomada. Como a solução ao problema não se encontra pré-concebida pela ordem jurídica, adotar o ponto de partida dos casualistas torna-se problemático quanto mais uma lide específica se repete.

\footnotetext{
32 Ainda será necessário investigar se casos tipicamente de direito privado ou de colisão entre liberdades, que tem uma menor repercussão política e social, poderiam ser resolvidos à maneira da vertente casualista, ao passo que as situações notoriamente de direito público ou de interesse coletivo, com maior repercussão política, econômica e social, deveriam ser resolvidas à luz do que propõem os abstracionistas. Esta distinção pode ser problemática, quando se visualiza as indeterminações entre direito público e privado. Talvez se pudesse empregar outra distinção, como aquela que se refere a interesses disponíveis e indisponíveis, sendo que os primeiros seriam enfocados pelos casualistas e os demais pelos abstracionistas. Ou ainda, seria possível valer-se da distinção entre interesses individuais, de um lado, e interesses coletivos de outro, para se referir a qual vertente seguir. Estas questões não serão enfrentadas neste artigo, de maneira que se optará por outro procedimento de argumentação, que tenta se afastar da polêmica destas distinções.
} 
Noutros termos, a recorrência de um problema fragiliza a posição de um julgador singular, na medida em que a cada caso que lhe for apresentado, ainda que a questão já tenha sido enfrentada anteriormente, novas teses e novas informações podem denunciar a parcialidade dos argumentos assumidos numa decisão anterior, o que pode levar a um processo instável de construção, desconstrução e reconstrução de uma solução equitativa. Além de pôr em cheque a ideia de segurança jurídica, tão cara ao Estado de Direito, haverá a desconfiança sobre a necessidade e a utilidade do uso da equidade, isto porque a mudança reiterada de solução para uma mesma situação, pode atrair para o intérprete a acusação de que interesses pessoais permeiam suas convicções.

Se todos estes argumentos não bastassem, não se pode ignorar que a pretensão da equidade é de alcançar uma solução mais perene (ainda que ela possa ser revisada), que ostente a pretensão de universalidade, ou, ao menos, que busque algum tipo de consenso razoável sobre qual é a melhor solução para o caso concreto, produzindo um efeito gravitacional em relação a outros casos similares. A equidade implicará na construção de um argumento que servirá para o caso concreto, mas que impactará em outros casos, e, assim, obrigará o julgador analisar, posicionar e, em casos mais importantes, até rever suas crenças mais profundas sobre os valores de justiça da ordem jurídica.

Por todos estes motivos, seria mais útil iniciar a tentativa para a solução do caso concreto a partir das teorias da justiça, como pretendem os abstracionistas ${ }^{33}$, pois, elas seriam capazes de oferecer um panorama mais amplo e organizado dos valores e princípios para uma Constituição, e, por conseguinte, para o ordenamento jurídico.

$\mathrm{O}$ próprio $\mathrm{Alexy}^{34}$, que se filia às teorias da argumentação (de caráter mais casualista) reconhece a

\begin{abstract}
${ }^{33} \mathrm{O}$ STF usa tanto a vertente casualista, quanto a abstracionista para decidir casos dificeis, sendo ambas aplicáveis ao contexto constitucional brasileiro. A vertente casualista já conta com um desenvolvimento significativo. Já o procedimento para a aplicação da vertente abstracionista ainda precisa ser melhor aprofundada, conforme é sugerido neste artigo. $\mathrm{O}$ artigo não tem a pretensão de afastar a validade e a importância das teorias da argumentação/da decisão judicial, mas, apenas, de apresentar outra maneira de se resolver casos dificeis.

${ }^{34}$ Alexy afirma que a tensão entre princípios e valores não pode ser solucionada com base na precedência absoluta e abstrata de cada um deles: "O 'conflito' deve, ao contrário, ser resolvido 'por meio de um sopesamento entre os interesses conflitantes'. $\mathrm{O}$ objetivo desse sopesamento é definir qual dos interesses - que abstratamente estão no mesmo nível - tem maior peso no caso concreto." (ALEXY, 2011, p.95). Portanto, por estarem num mesmo nível, deve-se considerar o suporte fático (condições pelas quais a consequência jurídica pode ocorrer) dos direitos/valores em colisão, sopesando-os de maneira a estabelecer os critérios racionais de precedência (condicionada) entre eles. Para ilustrar a forma de dimensionar os pesos (relativos) dos princípios Alexy vale-se de vários exemplos, como o do caso Lebach (ALEXY, 2011, p. 99-103). Neste caso, a televisão ZDF pretendia apresentar um documentário sobre um assassinato de quatro soldados. Um dos condenados como cúmplice, que já havia sido libertado, teria sua imagem exposta pela TV. O condenado argumentou que o documentário não deveria ir ao ar porque: 1) dificultaria sua ressocialização; 2) não haveria interesse atual pela informação. $\mathrm{Na}$ exemplificação do sopesamento, Alexy considera que existem dois princípios em colidência (liberdade de imprensa x intimidade), que prima facie podem se aplicar ao caso concreto. Alexy assenta, inicialmente, a importância do princípio da "transmissão de notícias atuais sobre crimes graves" (ALEXY, 2011, p. 172), porém, diante das condições 1) e 2) tal princípio cede espaço à proteção da privacidade do condenado, concluindo-se que: "( ... ) a repetição de uma notícia é qualificada como não suficientemente importante para justificar a intensidade da afetação." (ALEXY, 2011, p. 172). O exemplo, obviamente, é uma redução da teoria do autor. De toda forma, o que importa perceber é que o autor não aprofunda a discussão sobre a "preparação da ponderação", tampouco sobre a ordenação de qual princípio será tomado, em primeiro lugar, nos testes de sopesamento. No exemplo, tomou-se a liberdade de imprensa como ponto de partida, a qual
\end{abstract}


importância de se considerar as teses sobre princípios das teorias da justiça na "preparação da ponderação":

"Outras fundamentações, como aquelas que se baseiam no princípio do Estado de Direito, na prática jurisprudencial ou no conceito de justiça, não são por ela [proporcionalidade] excluídas. Na medida em que forem relevantes, são elas reforços bem-vindos à fundamentação a partir dos direitos fundamentais." (ALEXY, 201 1, p. 120).

E aqui surge mais uma pergunta: como existem várias teorias da justiça que apresentam uma visão abrangente sobre diversos problemas diferentes, e, que poderiam ser contraditórias entre si, como o intérprete deve proceder na escolha de uma ou de algumas teorias que o auxiliarão na construção da solução do caso concreto?

É comum, até por uma limitação humana, que os juristas, servidores e administradores públicos, ao usarem da equidade num sentido mais profundo, abracem certa teoria da justiça (ideologia) e a tomem como verdade absoluta. E, a par desta teoria, procuram transplantar, sempre que possível, suas proposições para resolver os problemas que lhes são apresentados.

Certamente esta posição é mais louvável que aquela, de caráter defensivo, que pretende revigorar o positivismo onde ele não tem incidência, ou, ainda escudar-se no "livre convencimento" para ocultar uma posição particular e, muitas vezes, não refletida com profundidade.

Entretanto, o ato de crença na verdade de uma teoria da justiça, seja ela de direita, de esquerda, republicana, utilitarista, feminista, ou de qualquer outra matriz, implica, de certo modo, numa posição pouco democrática, que pressupõe a possibilidade de uma teoria ser superior a qualquer outra, sem que se estabeleça um diálogo entre as proposições possíveis.

Essa compreensão privilegiada de uma única teoria da justiça esbarra num problema teórico grave, segundo o qual, na modernidade, a tolerância se aplica às próprias visões de mundo. ${ }^{35} \mathrm{Ou}$, para usar um termo mais específico, as teorias fundadas nas filosofias do sujeito, que são autorreferenciais, e que não ultrapassaram o crivo da filosofia da linguagem não podem ser empregadas no espaço público sem qualquer ressalva. É neste

encontrou seu limite frente ao princípio da intimidade nas condições 1) e 2). No entanto, a assunção da liberdade de imprensa (que também é invocada em outros conflitos, como por exemplo, no caso de segurança nacional; ALEXY, 2011, p. 149) como ponto de partida para a ponderação (e não a intimidade, ou, eventualmente outros princípios que poderiam ser invocados) pode ser justificada não somente de maneira restrita (porque consta numa Constituição), mas, porque remete a uma visão ideológica sobre outros princípios e outros valores da Constituição. Isso sugere que a teoria da argumentação de Alexy não é tão neutra quanto ele sugere (ALEXY, 2011, p. 178). Este é um assunto que merece aprofundamento numa outra oportunidade. De toda forma, estes são os pontos que se pretende abordar, evitando-se, porém, incorrer numa escolha aleatória de uma teoria que já pressuponha uma ordenação/hierarquia cardinal ou ordinal de valores (ALEXY, 2011, p. 159).

${ }^{35}$ Como afirma J. Ralws: "mesmo quando concordamos inteiramente com os tipos de consideração que são relevantes, podemos discordar a respeito de sua importância relativa e, assim, chegar a julgamentos diferentes.” (RAWLS, 2002a, p. 100). 
sentido, a crítica de Habermas ${ }^{36}$ e de tantos outros sobre a transposição automática e irrefletida sobre, por exemplo, a filosofia do direito de Kant para a atualidade. ${ }^{37}$

Portanto, ainda que um intérprete não domine mais de uma concepção de justiça, o que é plenamente compreensível, não pode, contudo, tomar a sua teoria preferida como dogma, como a única verdade possível sobre a justiça. ${ }^{38}$

Justificado o ponto de partida da argumentação, a partir da vertente abstracionista, passa-se a formular um procedimento para a redução da discricionariedade no julgamento por equidade.

\section{FUNDAMENTAÇÃO, CONSTITUIÇÃO E EXEMPLOS DE APLICAÇÃO DE UM PROCEDIMENTO RAZOÁVEL PARA MITIGAÇÃO DA ARBITRARIEDADE NO JULGAMENTO POR EQUIDADE}

Seria possível utilizar toda e qualquer teoria da justiça para orientar uma decisão equitativa? O que dizer sobre as teorias intolerantes? Sobre aquelas que não ostentam um caráter democrático? Ou que propõem formas radicais de igualitarismo, de liberalismo, ou de utilitarismo (apenas para citar algumas), que são incompatíveis com valores consagrados numa Constituição? O julgador deveria ser sensível a estas teorias?

A resposta, ao menos no plano teórico, seria negativa. Todavia, quando se vasculham os argumentos e as possibilidades de solução para um caso concreto, é difícil estabelecer uma hierarquia entre as teorias da justiça. Não que todos os argumentos possam ser tolerados e, certamente, alguns não serão, a exemplo, de uma proposta radicalmente igualitária que implicaria na abolição da propriedade privada, numa Constituição que consagra tal valor como cláusula pétrea. Mas, o fato de haver uma incompatibilidade radical entre a proposta teórica e as limitações do ordenamento jurídico, não inabilitam a teoria como um todo. Ou seja, mesmo teorias menos compatíveis com o texto constitucional podem servir como ponto de partida ou como contraponto a outra teoria empregada para a construção de uma solução equitativa para o caso concreto.

Se mais de uma teoria pode oferecer opções de respostas, antes de confrontá-las, deve-se tentar identificar pontos em comum. Perceba-se que os pontos em comum não dizem respeito aos fundamentos das próprias teorias, mas, somente quanto à solução para o caso concreto. Utilitaristas (consequencialistas) não concordam com Liberais (contratualistas) sobre quais princípios de justiça devem reger a sociedade. Apesar disso,

\footnotetext{
${ }^{36}$ Segundo Habermas: “(...) Kant não tinha respondido de forma inteiramente clara à questão da legitimação de leis gerais que deveriam fundamentar um sistema do egoísmo bem ordenado. Sua doutrina dos direitos não esclarece bem a relação entre princípio da moral, do direito e da democracia (...)" (HABERMAS, 1997, p. 122).

${ }^{37}$ Uma teoria explicativa para um caso, e, para outros casos similares é melhor que a solução oferecida pela interpretação positivista tradicional. Mas, a teoria da justiça que embasa tal decisão não é uma teoria explicativa de todos os valores de uma Constituição. Trata-se mais de uma orientação interpretativa do que de uma solução final para as disputas ideológicas em torno da Constituição.
} 
a aplicação de seus princípios pode convergir em alguns casos concretos, a exemplo, da ideia de se promover um mínimo existencial para pessoas menos favorecidas como propõem J. Rawls (liberal político) e A. Sen (utilitarista).

Caso seja possível encontrar tal ponto de contato, reforça-se o argumento em favor de uma solução, em detrimento de outras, que se mostram menos consensuais. Esse reforço não exclui a necessidade de reflexão sobre outras possibilidades de resolução do problema, mas, traz alguma autoridade para a tese que oferece um maior consenso teórico.

E aqui se levanta outro problema: se o julgador não pode se fechar para uma única solução do caso; se mesmo as visões mais radicais, e aparentemente incompatíveis com a Constituição, podem servir de pontos de partida (ou de contrapontos) para argumentação, então qual seria o limite para usar tais teorias?

Sejam elas mais ou menos compatíveis com os valores constitucionais, deve-se ter em mente que nenhuma teoria pode levar à desfragmentação da Constituição, ou, à hiperintegração (hiperdimensionamento) de um princípio/valor.

Esses termos são apresentados por Tribe e Dorf no livro "Hermenêutica Constitucional". Para estes autores, tanto a "des-integração" quanto a "hiper-integração" são falácias interpretativas, sendo assim conceituadas:

Quando nos referimos a ler por 'des-integração', significa nos aproximar da Constituição ignorando o fato claramente visível que suas partes estão ligadas ao todo - que é a Constituição que carece de interpretação e não um apanhado de cláusulas desconexas e meras provisões com históricos diversos. Quando nos referimos a ler por 'hiper-integração', significa nos aproximar da Constituição ignorando o não menos importante fato de que o todo é composto por partes - partes que em alguma instância foram adicionadas por uma ampla variedade de questões relativas à história da América; partes que são defendidas ou atacadas por grupos opostos e completamente diferentes entre si; partes que refletem premissas diferentes e, com frequência, radicalmente incompatíveis.

(...)

Essas observações parecem óbvias para o trabalho que deram. Mas elas servem ao menos para desqualificar muitas das possibilidades da argumentação e interpretação. Aqueles que por meio dos tempos procuram ver nessa complicada colagem de compromissos uma visão única, e aqueles que insistem em argumentar a partir dessa visão, não perceberam os sinais das pressões que nossa experiência impôs ao texto escrito da Constituição. O que eles estão lendo não é a nossa Constituição, e sim uma constituição hiper-integrada com a qual sonharam. (TRIBE; DORF, 2007, p. 20-1)

Tais limites interpretativos são utilizados por Tribe e Dorf no contexto de sua argumentação. Estas "lâminas" serão empregadas neste artigo para limitar os argumentos ("aparar arestas") das teorias da justiça que poderiam ser aplicados num caso concreto.

A desintegração constitucional pode ocorrer, por exemplo, ao adotar-se um argumento utilitarista tendente a justificar a restrição de liberdades individuais em prol de uma maior segurança para a maioria das

\footnotetext{
${ }^{38}$ Como adverte Virgílio Afonso da Silva não se aceita: “(...) a restrição aos seus direitos fundamentais de forma acobertada, por meio do recurso a intuições, muitas vezes moralistas, e a pré-compreensões mal-esclarecidas.” (SILVA, 2003, p. 49).
} 
pessoas. Como afirma Álvaro de Vita: "Há algo de muito errado com as concepções de justiça social que enfraquecem a posição dos que são mais vulneráveis." (VITA, 2000, p. 169) ${ }^{39}$. Os mesmos problemas interpretativos podem ocorrer com a supervalorização dos conceitos de posse, propriedade e de função social do direito privado. ${ }^{40}$

O valor "segurança", sem dúvida é fundamental para a ordem jurídica. Porém, a liberdade individual também é um valor relevante, o qual somente pode ser cerceado em situações muito específicas, previstas em lei. Nesses casos, ao colher-se apenas um valor como significativo, ignorando-se outro, incorre-se na desintegração da Constituição. Noutros termos, não se deve fazer da Constituição uma "colcha de retalhos", simplesmente porque se quer fazer valer uma convicção pessoal sobre a justiça.

A hiperintegração, pelo contrário, não representa um conflito entre valores genéricos, mas, uma hiperinflação de um valor ou princípio genérico em detrimento de uma regra constitucional expressa. É o que o ocorre, por exemplo, com o superdimensionamento da força do art. $5^{\circ}$, LIV e LV da Constituição, que versa sobre o devido processo legal. Como se sabe, uma teoria liberal como a de John Rawls toma esta garantia individual como um valor prioritário. Todavia, a Constituição brasileira prevê uma exceção expressa à referida cláusula em seu art. 71, III, consoante se extrai das discussões que levaram à edição da Súmula Vinculante n. ${ }^{\circ} 3$ pelo STF. ${ }^{41}$

Depois de realizados estes procedimentos de delimitação, ainda será necessário submeter a proposta de solução do caso concreto a alguns testes (de razoabilidade), verificando se ela: a) é justificável sob o ponto de vista das pessoas afetadas pela solução (teste de justificação); b) tem chances de vencer as soluções concorrentes e perdurar no tempo (teste de confrontação); c) apresenta fundamentos convincentes, capazes de modificar o entendimento sobre outras questões similares (teste de transcendência).

Estes testes podem ser aplicados aos precedentes anteriores citados.

\footnotetext{
${ }^{39}$ Ainda que os teóricos do processo penal tenham traçado vários critérios para tentar apreender o conceito genérico de "ordem pública”, não se pode ignorar que, em casos especiais, a interpretação deste conceito não oferece uma resposta perfeita e acabada. Ou seja, "ordem pública", a depender do caso concreto tenderá a justificar ou a afastar uma prisão cautelar, a depender da visão ideológica do magistrado sobre o que é um "Estado Democrático de Direito".

${ }^{40}$ Esta polêmica é ilustrada por Francisco Cardozo de Oliveira: "Embora defensável a possibilidade da existência de um direito subjetivo à moradia e ao acesso à terra, a partir do disposto no artigo $6^{\circ}$ da Constituição de 1988, que tutela os direitos sociais fundamentais à moradia e ao trabalho, no sentido defendido por Eros Roberto Grau (...), a premissa do direito constitucional de ser proprietário não contempla a hipótese de um direito subjetivo universal e abstrato de exigir em Juízo do Estado o direito à obtenção de imóvel para moradia ou área de terras no campo para cultivo. A premissa do direito constitucional de ser proprietário considera as circunstâncias do caso concreto que impõem ponderação de valores em torno da situação proprietária concreta e do conflito de interesses proprietários e não-proprietários." (OLIVEIRA, 2006, p. 275).

${ }^{41}$ Nas discussões que levaram a elaboração da Súmula Vinculante n. 3 do STF, o Min. Carlos Ayres Brito, acompanhando o voto da Min. Rel. Carmen Lúcia, entendeu que o art. 5०, LIV e LV da Constituição, que trata do devido processo legal, não se aplica ao caso do art. 71, III da Constituição, já que a própria Constituição afasta, expressamente, a incidência desta garantia pétrea: "Com essa ressalva final feita por Vossa Excelência quanto a aposentadorias, reformas e pensões, por se tratar de uma ressalva feita pela própria Constituição Federal, no inciso III do art. 71, sou pela aprovação." (p. 40 do voto).
} 
No caso das cotas para o acesso ao ensino público superior (ADPF n. $186 / \mathrm{DF}$ ) prevaleceu, no STF, o argumento de que somente existe efetiva igualdade de oportunidades se as pessoas forem situadas de maneira equitativa na competição por uma vaga. Nesse sentido, as condições de nascimento e as demais circunstâncias que afetam a (boa ou má) sorte de uma pessoa (a exemplo de nascer numa família carente de recursos financeiros, de estudar em escolas públicas, de integrar um grupo racial marginalizado) não poderiam preponderar no certame. Como o vestibular tradicional (com igualdade formal) ignora estas condições, ele não seria capaz de promover uma competição verdadeiramente justa.

O argumento seria justificável (a) sob o ponto de vista das pessoas afetadas pela solução (especialmente das que teriam mais dificuldades de serem aprovadas no vestibular com reserva de cotas), pelo fato de os candidatos mais favorecidos (ex: aqueles que estudaram em escolas privadas, de melhor qualidade, e que tem mais condições de renda) ainda teriam outras oportunidades de alcançar o ensino superior, seja porque poderiam pagar a mensalidade de uma instituição particular, seja porque poderiam valer-se de programas de financiamento das mensalidades (teste de justificação).

$\mathrm{O}$ argumento teria chances de vencer a solução concorrente (que insistia na igualdade formal do vestibular tradicional), (b) porque não impediria que as pessoas mais favorecidas (aquelas que normalmente são aprovadas nos vestibulares tradicionais) viessem a frequentar um curso superior numa instituição privada. Todavia, a solução contrária, ou seja, a manutenção do vestibular tradicional, certamente, impediria (ou dificultaria em demasia) o acesso de uma pessoa menos favorecida ao ensino público superior. Ou seja, ao passo que uma solução (da reserva de cotas) cria um ônus para o mais favorecido, sem excluí-lo, a outra (a tradicional), favorece o mais favorecido, impedindo/dificultando sobremaneira o acesso dos menos favorecidos. Se o que se busca é uma competição justa em que fatores arbitrários (como a condição de nascimento, etc.) não devam afetar o resultado da seleção, então, parece que a teoria que favorecesse o mais favorecido não é tão-convincente quanto à solução da teoria adotada pelo STF (teste de confrontação).

O argumento da teoria invocada pelo STF não só tem chances de perdurar por ser mais convincente que a proposição concorrente, mas (c) apresenta fundamentos que modificaram (ainda que implicitamente) o entendimento de outras questões similares, a exemplo do que se discutiu no Recurso Extraordinário n. ${ }^{\circ}$ 567.985/MT, no qual se afastou o critério (de igualdade formal) de miserabilidade previsto abstratamente em lei, para dar efetividade a outra forma de igualdade (material), que seria indispensável para se garantir chances razoáveis de alguém ter uma vida decente (teste de transcendência). Ou seja, também neste caso, a igualdade formal (perante a lei) cedeu espaço a outras formas de igualdade (de oportunidades/material).

Nos exemplos anteriormente comentados, ao menos por enquanto, o STF conseguiu demonstrar que a solução por ele encontrada passa pelos referidos testes. 
Todavia, se houver mais de uma teoria que os ultrapasse, aí a opção ideológica será inevitável. Nesse caso, a escolha ideológica, apesar de não ser neutra, deve deixar claro todas as suas premissas teóricas, pois, só assim será possível submetê-la à crítica e à eventual revisão. Ou seja, é indispensável que se revele a utilização desta ou daquela teoria (liberal, igualitária, utilitarista, republicana, etc.), que foi tomada como pressuposto da decisão, a fim de que se possa criticar a solução, aprofundar as discussões futuras e se ter um referencial argumentativo para solução de outros casos similares.

No fim, se os passos anteriormente sugeridos não forem suficientes para se chegar a uma conclusão razoável e justificada, restará um grau misterioso (decisionismo) na decisão a ser superado em algum momento, seja com a revisão do precedente, seja com a maior explicitação de seus fundamentos.

Em síntese, o procedimento razoável para a construção de uma solução equitativa está assim formulado: 1) identifica-se uma teoria da justiça, que possa fornecer uma solução para o caso concreto; 2) analisam-se os princípios de outras teorias da justiça, que também possam fornecer outras teses e soluções ao caso; 3) comparam-se as teorias, procurando identificar pontos de convergência quanto à solução do problema; 4) excluem-se aquelas que incorrem em desintegração ou em hiperintegração constitucional ${ }^{42}$; 5) avalia-se o princípio da teoria por meio do teste de razoabilidade, considerando-se o ponto de vista das pessoas afetadas pela solução, sendo vencedora a solução que suplante as concorrentes e perdure no tempo, tendo condições de modificar o entendimento sobre outras questões assemelhadas (testes de justificação, confrontação e de trasncendência) ; 6) restando apenas uma teoria que passa pelos referidos limites e testes, ter-se-á uma possível resposta, que ainda deverá ser submetida a uma revisão; 7) havendo mais de uma teoria que passe pelos referidos limites e testes, aí a opção ideológica será inevitável; 7.1.) a opção ideológica, apesar de não ser neutra, deve deixar clara todas as suas premissas teóricas, pois, só assim será possível submetê-la à crítica e à eventual revisão; 7.2.) se os passos anteriormente sugeridos não forem suficientes para se chegar a uma conclusão razoável e justificada, a decisão sustentará um grau de arbitrariedade, a ser superado em algum momento, seja com a revisão do precedente, seja com a explicitação de seus fundamentos ${ }^{43}$.

\footnotetext{
${ }^{42}$ Similarmente, ilustra Alexy: "Não há dúvida de que há princípios que, se surgissem em um determinado ordenamento jurídico, seriam declarados inválidos no primeiro confronto como outros princípios. Um exemplo seria o princípio da segregação racial. (... ) Não se pode dizer que haja alguma situação em que esse princípio tenha preferência e outros em que não tenha; enquanto valerem os princípios do atual direito constitucional, esse princípio será preterido em todos os casos, o que significa que ele não é válido." (ALEXY, 2011, p. 110).

${ }^{43}$ Alexy dá um passo adiante neste procedimento afirmando que a lei de sopesamento tornaria possível diminuir ainda mais o decisionismo por meio da seguinte fórmula: "Quanto maior for o grau de não-satisifação ou de afetação de um princípio, tanto maior terá que ser a importância da satisfação de outro.” (ALEXY, 2011, p. 167). Esta fórmula, que estaria num metanível em relação aos princípios colidentes, possibilitaria a vinculação entre os princípios colidentes e a regra (critério) a ser enunciada para o caso concreto. Essa otimização dos princípios e sua correlata restrição ao princípio de menor peso, como já anunciado anteriormente, não é neutra. A tarefa da ponderação certamente contribuirá no esclarecimento das premissas argumentativas, no entanto, para casos difíceis é importante conservar a cautela quanto à força (e a controvérsia) dos argumentos ideológicos (das teorias da justiça), que subjazem ao caso concreto.
} 
O uso de um procedimento argumentativo, apesar de trabalhoso e complexo, pode corroborar para a construção e o esclarecimento da própria Constituição, gerando não só a estabilização dos princípios e valores pressupostos nas opiniões e decisões dos intérpretes do direito, mas, também fomentando uma cultura geral para os cidadãos, os quais, quiçá tenderão a melhorar a qualidade de suas posições, no sentido de elas tornaram-se mais razoáveis.

\section{CONCLUSÃO}

Apesar da desconfiança e da ainda tímida aceitação do uso da equidade, este recurso interpretativo é valoroso, na medida em que pretende evitar a tomada de decisões arbitrárias.

Para realçar este propósito apresentou-se a distinção entre a vertente casualista e a abstracionista, destacando-se que ambas pressupõem a insuficiência do ordenamento jurídico e que a equidade, para sua incidência, independente de previsão normativa, podendo modular, adaptar e até diminuir a força dos institutos clássicos do direito.

Ao enfocar a vertente abstracionista, mostrou-se que ela, para justificar sua pertinência, ataca a insuficiência dos pressupostos epistemológicos do positivismo jurídico e procura preencher as cláusulas genéricas da Constituição a partir de teorias gerais da justiça de diferentes matrizes, as quais estão exemplificadas em diversas decisões do Supremo Tribunal Federal.

A partir do conceito de "razoabilidade" apresentado por John Rawls, o qual opõe-se a ideia de "racionalidade" como estratégia (interesse parcial) para se alcançar um objetivo, formulou-se um procedimento razoável que pretende ser imparcial na orientação da escolha dos princípios e valores das teorias da justiça a incidirem no caso concreto.

Apesar de não haver um consenso sobre quais teorias da justiça seriam as mais adequadas para resolver um caso difícil, o referido procedimento sugere a necessidade de se tomar uma teoria (da vertente abstracionista) como ponto de partida, a fim de se ter um panorama inicial de uma solução possível. Em seguida, deve-se procurar pontos de convergência entre teorias concorrentes, excluindo-se aquelas que incorrem em desintegração ou hiperintegração do texto constitucional. Posteriormente realizam-se os testes de justificação, confrontação e transcendência a fim de averiguar qual é a mais razoável. Caso ainda reste mais de uma opção válida para a solução do caso concreto, aí a opção ideológica, que será inevitável, deverá ser assumida explicitamente, a fim de que possa ser criticada, revisada e indicar o cenário argumentativo para soluções futuras em questões assemelhadas.

Ainda que o objetivo da equidade seja o de tornar conhecido o conceito de justiça aplicado ao caso concreto, inevitavelmente, alguns pontos da decisão permanecerão na penumbra. Caso se pretenda fazer um bom uso da equidade, demonstrando que ela é melhor que a lei e o precedente já conhecido, é necessário que se 
procure argumentar, esclarecer e justificar a opção ideológica adotada como pano de fundo para a decisão, para que o temor quanto ao mistério que a envolve se dissipe e dê lugar a decisões mais justas.

\title{
A REASONABLE PROCEDURE FOR FAIR JUDGMENT: THE ABSTRACTIONIST POSITION
}

\begin{abstract}
This article addresses the justification and the formulation of a reasonable procedure to guide fair judgment. Fairness is the recourse of the interpreter against the law and the judicial precedent, when the latter produce unfair results. Given the risk of arbitrariness in fair judgment, this article investigated the possibility of justifying, building and exemplifying the application of a reasonable procedure for fair judgment, from the abstractionist point of view, in an attempt to reduce the interpreter's discretion. The methodology consisted of the empirical analysis of Brazilian Supreme Court precedents that applied certain principles of legal theory, followed by the introduction of John Rawls's concept of reasonableness and the formulation of a procedure able to identify the legal theory that provides a solution to the concrete case, allowing for the analysis of opposing theories, after which it should concentrate on points of convergence and exclude arguments that cause constitutional disintegration or hyperintegration (delimitation test). After that the degree of impartiality and reasonableness of the proposition should be evaluated by means of justification, confrontation and transcendence tests. In case there is still more than one option to solve the case, the ideological option should be explicitly stated so that it may be criticized and revised.
\end{abstract}

Keywords: fairness, abstractionism, procedure, reasonableness.

\section{REFERENCIAS BIBLIOGRÁFICAS}

ALEXY, Robert. Teoria dos direitos fundamentais. Trad. Virgílio Afonso da Silva, São Paulo: Malheiros, 2011.

ARISTÓTELES. Ética a Nicômacos. 4a ed. trad. Mário da Gama Kury, Brasília: UNB, 2001.

AUDARD, Catherine. John Rawls. Montreal: McGill-Queen's University Press, 2007.

ÁVILA, Humberto. Teoria dos princípios: da definição à aplicação dos princípios jurídicos. $7^{a}$ ed., São Paulo: Malheiros, 2007,

BOBBIO, Norberto. Direita e esquerda: razões e significados de uma distinção política. Trad. Marco Aurélio Nogueira. 2a ed. São Paulo: Editora UNESP, 2001.

BRASIL. Constituição (1988). Constituição da República Federativa do Brasil. Texto constitucional promulgado em 5 de outubro de 1988, com as alterações até a Emenda n. ${ }^{\circ}$ 90/2015. Brasília: 2015, 124 p. Disponível em: http://www2.camara.leg.br/atividade-

legislativa/legislacao/Constituicoes_Brasileiras/constituicao1988.html/ConstituicaoTextoAtualizado_EC90.p df. Acesso em 10 jan. 2015.

Supremo Tribunal Federal. Ação direta de inconstitucionalidade nº 4650/DF - Distrito Federal. Relator 


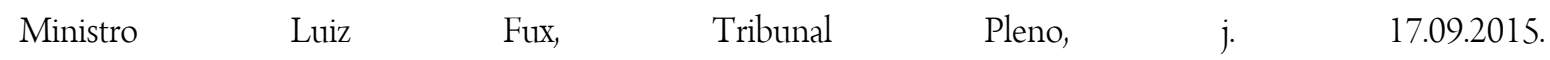

http://www.stf.jus.br/arquivo/cms/noticiaNoticiaStf/anexo/ADI4650relator.pdf. Aceso em 10 jan. 2015.

Supremo Tribunal Federal. Arguição de Descumprimento de Preceito Fundamental n. ${ }^{\circ}$ 54/DF,

Ministro Relator Marco Aurélio, Tribunal Pleno, j. 12.04.2012, DJe-080, p. 30.04.2013. $<$ http://redir.stf.jus.br/paginadorpub/paginador.jsp?docTP=TP\&docID=3707334> Acesso em 10 jan. 2015.

Supremo Tribunal Federal. Arguição de Descumprimento de Preceito Fundamental n. ${ }^{\circ}$ 186/DF,

Ministro Relator Ricardo Lewandowski, Tribunal Pleno, j. 26.04.2012, DJe-205, p. 20.10.2014. http://redir.stf.jus.br/paginadorpub/paginador.jsp?docTP=TP\&docID=6984693

Acesso em 10 jan. 2015.

Supremo Tribunal Federal. Habeas Corpusn. ${ }^{\circ}$ 84078/MG, Ministro Relator Eros Grau, Tribunal Pleno,

j. 05.02.2009, DJe-035, p. 26.02.2010, Ement. Vol. 02391-05, p. 1048. http://redir.stf.jus.br/paginadorpub/paginador.jsp?docTP=AC\&docID=608531. Acesso em 10 jan. 2015.

Supremo Tribunal Federal. Habeas Corpus n. ${ }^{\circ}$ 95009/SP, Ministro Relator Eros Grau, Tribunal Pleno, j. 06.11.2008, DJe-241, p. 19.12.2008, Ement. Vol. 02346-06, p. 1275, RTJ vol. 00208-02, p. 00640. http://redir.stf.jus.br/paginadorpub/paginador.jsp?docTP=AC\&docID=570249. Acesso em 10 jan. 2015.

Supremo Tribunal Federal. Recurso Extraordinário n. ${ }^{\circ}$ 567.985/MT, Ministro Relator Marco Aurélio, $\begin{array}{llllll}\text { Tribunal Pleno, } & \text { j. } & 18.04 .2013, & \text { DJe-194, } & \text { p. } & \text { 03.10.2013. }\end{array}$ http://redir.stf.jus.br/paginadorpub/paginador.jsp?docTP=TP\&docID=4614447. Acesso em 10 jan. 2015.

Supremo Tribunal Federal. Recurso Extraordinário n. ${ }^{\circ}$ 581.488/RS, Ministro Relator Dias Toffoli, Tribunal Pleno, j. 03.02.2015. http://www.stf.jus.br/arquivo/cms/noticiaNoticiaStf/anexo/RE581488DT.pdf. Acesso em 10 jan. 2015.

DAHL, Robert. A democracia e seus críticos. Trad. Patrícia de Freitas Ribeiro, São Paulo: Editora WWF Martins Fontes, 2012.

DOBROWOLSKI, Samanhta Chantal. Uma teoria da justiça para os dilemas da sociedade contemporânea: anotações em torno da resposta liberal de John Rawls. In Filosofia e teoria constitucional contemporânea. Coord. Daniel Sarmento, Rio de Janeiro: Lumen Juris, 2009, p. 577-611.

DWORKIN, Ronald. Levando os direitos a sério. Trad. Nelson Boeira. São Paulo: Martins Fontes, 2002.

HABERMAS, Jürgen. Direito e democracia: entre facticidade e validade. v. 1 e 2 trad. Flávio Beno Siebeneichler. Rio de Janeiro: Tempo Brasileiro, 1997.

KANT, Immanuel, A metafísica dos costumes, trad. Edson Bini, Bauru: EDIPRO, 2003.

KELSEN, Hans. Teoria Pura do Direito, trad. João Baptista Machado, 6ª ed., São Paulo: Martins Fontes, 2003.

KYMLICKA, Will. Filosofia Política Contemporânea, trad. Luis Carlos Borges, São Paulo: Martins Fontes, 2006.

OLIVEIRA, Francisco Cardozo. Hermenêutica e tutela da posse e da propriedade. Rio de Janeiro: Forense, 2006.

PALOMBELA, Gianluigi. Filosofia do Direito. Trad. Ivone C. Benedetti. São Paulo: Martins Fontes, 2005.

PERELMAN, Chaïm. Ética e direito. Trad. Maria Ermantina Galvão. São Paulo: Martins Fontes, 1996.

RAWLS, John. O liberalismo político. 2a ed. trad. Dinah de Abreu Azevedo. São Paulo: Editora Ática, 2000a. Uma teoria da justiça. $2^{a}$ ed. Trad. Almiro Pisetta; Lenita Maria Rímoli Esteves. São Paulo: Martins 
Fontes, 2002a.

Justiça e democracia. Trad. Irene A. Paternot. São Paulo: Martins Fontes, 2002b.

Justiça como eqüidade: uma reformulação. Trad. Claudia Berliner. São Paulo: Martins Fontes, 2003.

Conferências sobre a história da filosofia política. Trad. Fabio M. Said. São Paulo: Martins Fontes, 2012.

SCHMITT, Carl. El Leviathan em la teoría del Estado de Thomas Hobbes. Trad. Francisco Javier Conde, Granada: Editoral Comares, 2004.

SILVA, Virgílio Afonso. O conteúdo essencial dos direitos fundamentais e a eficácia das normas constitucionais. In: Revista de Direito do Estado, Rio de Janeiro: Renovar, n. 4, pp. 23-51, out/dez 2006.

SOUZA NETO, Cláudio Pereira de. SARMENTO, Daniel. Direito Constitucional: teoria, história e métodos de trabalho, Belo Horizonte: Fórum, 2012.

TRIBE, Laurence; DORF, Michael. Hermenêutica constitucional. Trad. Amarílis de Souza Birchal, Belo Horizonte: Del Rey, 2007.

VARGAS, Jorge de Oliveira. Julgamento por equidade. Curitiba: Juruá, 2015.

VITA, Álvaro de. A justiça igualitária e seus críticos. São Paulo: Editora UNESP, 2000.

WALZER, Michael. Esferas da justiça: uma defesa do pluralismo e da igualdade. Trad. Jussara Simões, São Paulo: Martins Fontes, 2003.

ZAGREBELSKY, Gustave. El derecho dúctil. Ley, derechos, justicia. Trad. Marina Gascón, Madrid: Editorial Trotta, 2011.

ZOLO, Danilo. Teoria e crítica do Estado de direito. In: O Estado de Direito: história, teoria, crítica; org. COSTA, Pietro; ZOLO, Danilo. Trad. Carlo Alberto Dastoli, São Paulo: Martins Fontes, 2006.

Trabalho enviado em 20 de julho de 2017.

Aceito em 28 de julho de 2017. 